J. Clin. Chem. Clin. Biochem.

Vol. 26, 1988, pp. 543-547

(C) 1988 Walter de Gruyter \& Co.

Berlin - New York

\title{
Lipid and Lipoprotein Contents of Human Follicular Fluid
}

\author{
By Ernest Suchanek, Velimir Šimunić, Branko Kopjar, Ervin. Maćaš, Veselko Grizelj \\ Department of Gynecology and Obstetrics, School of Medicine, University of Zagreb
}

Branka Salzer and Ana Stavljenić

Institute of Clinical Laboratory Diagnostics, Clinical Hospital Center, School of Medicine, University of Zagreb, Zagreb, Yugoslavia

(Received September 11, 1987/May 19, 1988)

Summary: The concentrations of total cholesterol, phospholipids, triacylglycerols and lipoproteins were measured in 87 follicular fluids obtained from 35 women undergoing in vitro fertilization and embryo transfer. The results were correlated with the levels of progesterone in follicular fluid. Two different types of ovarian stimulation were used. High density lipoproteins were the dominant lipoproteins found in the preovulatory follicular fluid. Low density lipoproteins were absent or appeared in trace amounts. Significantly higher triacylglycerol and high density lipoprotein levels were found when stimulation with human menopausal gonadotropins and chorionic gonadotropin was applied, as compared to the clomiphene citrate-menopausal gonadotropin-chorionic gonadotropin menstrual cycle. In both groups, extracorporal fertilization resulted in cleavage of oocytes and embryo transfer. No significant correlation between any follicular fluid lipid and progesterone concentration was found. The lipids estimated in the follicular fluid appeared to have no influence on the oocyte fertilizability. The presence of triacylglycerols and high density lipoproteins in the follicular fluid may indicate follicular wall permeability under the treatment with menopausal gonadotropins.

\section{Introduction}

The human preovulatory oocyte microenvironment undergoes profound changes shortly before ovulation. Between 25 and 36 hours after the onset of the luteinizing hormone surge or human chorionic gonadotropin administration, the oocyte maturation proceeds from prophase I to metaphase II stage. Effective amoünts of luteinizing hormone enter the follicular fluid simultaneously with the emergence of a preovulatory peak of luteinizing hormone in plasma. Entry of luteinizing hormone into the follicle stimulates the resumption of granulosa cell luteinization. As a consequence of a vigorous steroidogenesis in the preovulatory follicle, ovulation is preceded by an increase of plasma progesterone. The concentration of progesterone in the follicular fluid increases, while oestradiol and androstenedione concentrations decline (1). Granulosa cells may be the main source of progesterone and oestrogens within the follicle. At this stage, the biochemical composition of follicular fluid reflects the degree of follicular maturation.

In the ovary, progesterone is synthesized from cholesterol which may be derived from any of three sources: de novo synthesis from 2-carbon units, mobilization of intracellularly stored cholesterol ester, or uptake from extracellular lipoproteins.

Cholesterol derived from lipoprotein has been reported to be of crucial importance for steroid production, and low density lipoproteins appear to be the most important source of cholesterol in the human ovary $(2,3)$.

Addition of low density lipoproteins, but not high density lipoproteins, to human granulosa cells cultured in a lipoprotein-free medium in the presence of 
gonadotropins, resulted in a dose-dependent increase in the production of progesterone (3). Human corpus luteum and cultured granulosa cells possess a specific receptor-mediated mechanism for the uptake of low density lipoproteins and for the utilization of low density lipoproteins, preferentially as a source of cholesterol substrate (4). In contrast, it was shown by Simpson et al. (5) that the follicular fluid of human ovaries at various stages of the normal menstrual cycle contained little or no low density lipoproteins or very low density lipoproteins, while the concentration of high density lipoproteins approached that found in plasma. It was suggested that the lack of biosynthetic substrate was the main reason for the limited progesterone production on preovulatory follicles.

In view of the crucial role of cholesterol in ovarian steroidogenesis, a study was undertaken to evaluate the possibility of considering lipids and lipoproteins as markers of follicular maturation. The concentrations of cholesterol, phospholipids, triacylglycerols and lipoproteins in the follicular fluid were correlated with the concentration of follicular fluid progesterone, as well as with the fertilization of oocytes derived from cycles stimulated by two types of ovarian induction for in vitro fertilization.

\section{Materials and Methods}

\section{Patients and treatment}

Preovulatory follicular fluids were obtained from 35 women, who where infertile due to tubal absence, and expected to undergo extracorporal fertilization and embryo transfer. They were aged 24-38 years and had regular menstrual cycles ( $30 \pm 4$ days).

To stimulate follicular growth, clomiphene citrate (Clomiphene, Richardson-Merrell-Belupo, Yugoslavia) was given to 26 women during 5 days, in a dose of $100 \mathrm{mg}$ daily, starting from the fourth or fifth day of the menstrual cycle. On the last day of clomiphene administration, ovulation was induced with human menopausal gonadotropins (Pergonal, Serono, W. Germany). The dose varied depending on the growth of dominant follicles and on the daily rise in serum oestradiol. When the two largest follicles measured by ultrasound (Toshiba Real Time Scanner, Japan) were at least $16 \mathrm{~mm}$ in diameter and serum oestradiol concentrations were above $1.4 \mathrm{nmol} / 1$ per follicle, 5000 IU of chorionic gonadotropin (Pregnyl, Organon, Holland) were given. Laparoscopic aspiration of the follicles was performed $34-36 \mathrm{~h}$ later.

In 9 patients, follicular growth was induced with $150 \mathrm{IU}$ of menopausal gonadotropins on the third and fourth day of the cycle. Thereafter, the dose of menopausal gonadotropins was gradually increased, depending on the individual response. Chorionic gonadotropin was given intramuscularly $34-36 \mathrm{~h}$ before laparoscopy and oocyte retrieval, in a dose of $10000 \mathrm{IU}$.

\section{In vitro fertilization}

All specimens were microscopically examined, the oocyte-corona-cumulus complexes identified, and a culture set up in a modified HAM's F-10 medium (Seromed, W. Germany) at $37^{\circ} \mathrm{C}$ in a humidified atmosphere of $5 \% \mathrm{CO}_{2}, 5 \% \mathrm{O}_{2}$ and $90 \%$ $\mathrm{N}_{2}$ (Heraeus, W. Germany). The insemination medium was supplemented with $10 \%$ newborn beat-inactivated cord serum $\left(30 \mathrm{~min}\right.$ at $\left.55^{\circ} \mathrm{C}\right)$. Oocyte-corona-cumulus complexes were preincubated for $4-6 \mathrm{~h}$ before introducing the sperm prepared by washing twice with the insemination medium. The spermatozoa were then isolated by centrifugation $(300 \mathrm{~g}$ for $10 \mathrm{~min}$ ) and resuspended in the medium. To each culture of oocytecorona-cumulus complex, $0.33 \pm 0.18 \times 10^{6}$ of motile sperm was added. Eighteen hours after insemination, mechanically denuded oocytes were moved to the growth medium enriched with $20 \%$ serum. The culture was continued for an additional 24 h.

Follicular fluids were centrifuged at $1000 \mathrm{~g}$ and the cell-free liquid stored at $-20^{\circ} \mathrm{C}$ pending assay. Any blood-contaminated samples (determined with the Haemoglobinometer, Coulter Electronics Ltd., UK) were discarded. Sixty two samples from clomiphene-menopausal gonadotropin and 25 from menopausal gonadotropin cycles were analysed.

\section{Lipid, lipoprotein and hormone assays}

Total cholesterol (7), total phospholipids (8) and triacylglycerols in follicular fluid were assayed by enzymatic methods (BioMerieux, France; Code Nos. 61224, 61491 and 61236, respectively). LDLs were precipitated by polycondensed polycyclic anionic surface-active agents in imidazole buffer (BioMerieux, France; Code No. 61532), and the separation of HDLs was performed by polyethylene glycol precipitation (10) from follicular fluid (Immuno AG, Austria; Code No. 8251015). These fractions were analysed for bound cholesterol.

The lipid content of follicular fluid is expressed as the concentration of lipids in $1 \mathrm{~g}$ of total proteins. Protein was estimated using the Folin phenol reagent according to the method of Lowry et al. (11).

Serum oestradiol and follicular fluid progesterone concentrations were measured by radioimmunoassay using a direct technique (12). Reagents were from Biodata Laboratories (Italy):

As the concentration of progesterone in human follicular fluid is known to be high, the samples were diluted $1: 1000$ prior to assaying with $0.01 \mathrm{~mol} / 1$ phosphate buffer $(\mathrm{pH}, 7.5)$. As diluted samples and standard preparations give parallel plots for the displacement of radiolabelled steroid (13), follicular fluids were not extracted with the solvent before the assay.

Between-run precision studies yielded variation coefficients of $9 \%$ for serum oestradiol, $12 \%$ for follicular fluid progesterone, and $5 \%-11 \%$ for the concentrations of lipids and lipoproteins.

The results are expressed as mean \pm SD values. Statistical analysis of follicular fluid lipid, lipoprotein and progesterone concentrations, differences among the groups according to the type of follicular growth induction, and the result of in vitro fertilization were calculated by Kruskal-Wallis one-way ANOVA (14). The correlation between follicular fluid lipids and progesterone concentration is expressed as a Spearman rank correlation coefficient, with $p$ values below 0.05 considered to be significant.

\section{Results}

In $47(75.8 \%)$ out of 62 follicular fluids of clomiphene-gonadotropin cycles, the oocytes obtained were found to have been fertilized and undergone cleavage. The remaining $15(24.2 \%)$ oocytes were not fertilized. In the cycles stimulated with menopausal gonadotropins, only 19 fluids yielded fertilizạble oocytes $(76 \%)$, while in $6(24 \%)$ cycles fertilization failed. 
Tab. 1. Follicular fluid concentrations of lipids, HDL-cholestcrol and progesterone (mean \pm SD), depending on the type of ovarian induction and the result of in vitro fertilization.

\begin{tabular}{|c|c|c|c|c|c|}
\hline $\begin{array}{l}\text { Type of ovarian induction/ } \\
\text { Result of in vitro fertilization }\end{array}$ & $\begin{array}{l}\text { Cholesterol } \\
\text { ( } \mu \mathrm{mol} / \mathrm{g} \text { total } \\
\text { proteins })\end{array}$ & $\begin{array}{l}\text { Phospholipids } \\
\text { ( } \mu \text { mol/g total } \\
\text { proteins }\end{array}$ & $\begin{array}{l}\text { Triacyl- } \\
\text { glycerols } \\
\text { ( } \mu \text { mol } / \mathrm{g} \text { total } \\
\text { proteins })\end{array}$ & $\begin{array}{l}\text { HDL- } \\
\text { cholesterol } \\
\text { ( } \mu \mathrm{mol} / \mathrm{g} \text { total } \\
\text { proteins })\end{array}$ & $\begin{array}{l}\text { Progestcronc } \\
\text { (nmol/g lotal } \\
\text { proteins) }\end{array}$ \\
\hline $\begin{array}{l}\text { 1. Clomiphene-gonadotropins, } \\
\text { fertilization }(n=47)\end{array}$ & $13.1 \pm 2.8$ & $19.5 \pm 3.8$ & $7.3 \pm 3.5$ & $3.9 \pm 1.2$ & $432.5 \pm 376.4$ \\
\hline $\begin{array}{l}\text { 2. Clomiphene-gonadotropins, } \\
\text { no fertilization }(n=15)\end{array}$ & $15.3 \pm 8.6$ & $19.7 \pm 3.8$ & $6.1 \pm 1.8$ & $4.3 \pm 1.4$ & $337.7 \pm 258.2$ \\
\hline $\begin{array}{l}\text { 3. Gonadotropins, } \\
\text { fertilization }(\mathrm{n}=19)\end{array}$ & $17.9 \pm 9.9$ & $24.7 \pm 13.5$ & $9.8 \pm 4.2^{*}$ & $7.5 \pm 3.2^{* *}$ & $276.9 \pm 171.2$ \\
\hline $\begin{array}{l}\text { 4. Gonadotropins, } \\
\text { no fertilization }(n=6)\end{array}$ & $15.1 \pm 6.2$ & $19.6 \pm 5.6$ & $6.1 \pm 1.9$ & $4.9 \pm 1.9$ & $210.3 \pm 127.2$ \\
\hline Significance & N.S. & N.S. & ${ }^{*} \mathrm{p}<0.05$ & ${ }^{* *} \mathrm{p}<0.005$ & N.S. \\
\hline
\end{tabular}

Data for the concentrations of lipids, lipoproteins and progesterone in follicular fluid are shown in table 1. The difference between the follicular fluid triacylglycerols in clomiphene-gonadotropin and in gonadotropin-only cycles was found to be significant $(p<0.05)$. Low density lipoproteins in the follicular fluid were either not found or appeared in trace amounts. The precipitation technique used for lipoprotein determination was checked by ultracentrifugation and cellogel electrophoresis. We could not find any significant difference by measuring lipoproteins using the precipitation method. The concentration of high density lipoprotein cholesterol found in the follicular fluid from clomiphene-gonadotropin cycles represented $31.7 \% \pm 9.2 \%$ of total cholesterol measured. A significantly elevated $(p<0.005)$ high density lipoprotein concentration was detected in gonadotropin-fertilization cycles. The high density lipoprotein cholesterol concentration in all fluids from gonadotropinonly cycles was $27.1 \% \pm 9.3 \%$ of the total cholesterol amount. The concentration of progesterone in preovulatory follicular fluid did not differ significantly among the groups studied. Higher values were observed in all clomiphene-gonadotropin fluids (405.5 $\pm 349.2 \mathrm{nmol} / \mathrm{g}$ total proteins) as compared with all gonadotropin-only fluids $(260.3 \pm 161.4 \mathrm{nmol} / \mathrm{g}$ total proteins), but the difference was not significant. No significant correlation was recorded between any follicular fluid lipid and progesterone concentrations. A negative insignificant correlation (Spearman rank correlation coefficient: $-0.136, p>0.05$ ) was found between the high density lipoprotein cholesterol and progesterone concentrations in the follicular fluids from both types of ovarian induction when oocytes were fertilized in vitro.

\section{Discussion}

Luteinizing granulosa cells are a primary source of progesterone secreted by the ovulatory follicle (15). The studies of Hillier \& Wickings (16) have shown that both the production of progesterone in granulosa cells and the concentration of follicular fluid progesterone increase as the follicle approaches ovulation. Between the starting moment of the luteinizing hormone surge and that of the follicular rupture, the progesterone-producing capacity of luteinizing granulosa cells increases more than a hundred times.

A critical role of cholesterol in steroidogenesis within the follicle has been proposed by Berger et al. (17). They found a direct linear correlation among cholesterol, oestradiol and progesterone in follicular fluid. However, these findings could not be confirmed by our experiment. Higher, but not statistically significantly, concentrations of cholesterol in the follicular fluid in gonadotropin induction when extracorporal fertilization was successful, could be the result of permeability changes within the follicle under the influence of gonadotropins. Higher doses of gonadotropins given in gonadotropin cycles as compared to clomiphene-gonadotropin cycles may be responsible for molecular sieve changes of the blood-follicle barrier, facilitating the passage of lipids in an inverse proportion to the molecular weight and size. Such an explanation was originally proposed by Shalgi et al. (18) for follicular fluid proteins.

Our study has demonstrated that about $30 \%$ of the lipids are recovered in the high density lipoprotein fraction. Low density lipoproteins were absent from the follicular fluid or present in trace amounts only, 
which is in agreement with previous observations (5, 17, 19). The transport form of the majority of the remaining lipids in follicular fluid is unknown. It has been suggested that the very low levels of low density lipoproteins in preovulatory follicle are responsible for the low progesterone production (5). However, this is negated by the high levels of progesterone found in follicular fluid $(1,11,17,20)$. When the plasma progesterone level reaches its maximum during the mid-luteal phase, the corpus luteum secretes more than $7.8 \mathrm{nmol}$ of progesterone per day (16). Since this rate of production is too high to be sustained by steroid synthesized from endogenous cholesterol, an exogenous source must also be introduced. Granulosa-lutein cells, like many other cells, can derive unesterified cholesterol from the uptake and degradation of low density lipoproteins (3). The uptake can be stimulated by chorionic gonadotropin and requires interaction of low density lipoproteins with specific receptors in the cell membrane (2). Cholesteryl esters of low density lipoproteins are hydrolysed by the action of cholesteryl esterase ${ }^{1}$ ), which in turn, is increased in response to luteinizing hormone action. Thus liberated cholesterol is available for progesterone biosynthesis.

Follicular fluid contains high density lipoproteins at a concentration approximately half that in serum. High density lipoproteins may be consumed to provide cholesterol within the preovulatory follicle by the mechanism described by Enk et al. (21). Recently, they have shown that human granulosa cells can utilize cholesterol carried by high density lipoproteins as well as low density lipoproteins for progesterone synthesis in vitro. The identification of specific highaffinity high density lipoprotein-receptor sites in human corpus luteum membranes (22) suggests that a receptor-mediated high density lipoprotein pathway may exist in human steroidogenic tissues. The functional characteristics of high density lipoprotein receptors have so far not been delineated in humans. Using the whole high density lipoprotein fraction, the enhancing effect on progesterone production found in the study of Enk et al. (21) might be due to a

1) Enzyme: Cholesteryl esterase (EC 3.1.1.13)

\section{References}

1. McNatty, K. P. (1978) In: The Vertebrate Ovary. Comparative Biology and Evolution, (Jones, R. E., ed.) pp. 215259, Plenum Press, New York.

2. Carr, B. R., Sadler, R. K., Rochelle, D. B., Stalmach, M. A., McDonald, P. C. \& Simpson, E. R. (1981) J. Clin. Endocrinol. Metab. 52, 875-881. higher relative cholesterol content. The saturable progesterone response is indicative of a receptor-mediated cholesterol uptake.

The presence of high density lipoproteins is related to the high steroidogenic activity of the follicle cells. After ovulation, changes in follicular vascularization permit the low density lipoprotein-granulosa cell interactions and, thus, the acquisition of cholesterol from low density lipoproteins, high density lipoproteins, or both. In the present study, a strict relationship between the follicular fluid high density lipoprotein and progesterone concentrations was not found. Hypothetically, because of a negative correlation tendency, liquids with high progesterone may contain low concentrations of high density lipoproteins, suggesting the consumption of these lipoproteins as a source of cholesterol.

The phospholipid and triacylglycerol concentrations in follicular fluid found in our study were about $30 \%$ and $20 \%$ of the corresponding values in serum, respectively. The origin of triacylglycerols in the follicular fluid is unknown. Significant differences in the triacylglycerol contents after two different modes of ovarian stimulation may have resulted from microenvironmental changes within the preovulatory follicle.

The absence of any differences in the lipid content between the follicular fluids obtained from unfertilized and fertilized samples suggest that the lipids taken into consideration seem to be of no significance in the ability of oocyte to be successfully fertilized in vitro.

More appropriate experimental arrangements, such as granulosa cell culture experiments using labelled precursors, should be used to obtain clear conclusions on the source of cholesterol for the synthesis of progesterone.

\section{Acknowledgement}

Authors are indebted to Mrs. Nada Ribic for her skilful technical assistance.

Supported in part by a Research Grant No 2.04.01.03.10 from the Republic Community for Science of Croatia, Zagreb, Yugoslavia.
3. Tureck, R. W. \& Strauss, J. F. (1982) J. Clin. Endocrinol. Metab. $54,367-373$.

4. Ohashi, M., Carr, B. R. \& Simpson, E. R. (1982) Endocrinology $110,1477-1482$.

5. Simpson, E. R., Rochelle, D. B., Cari, B. R. \& MacDonald, P. C. (1980) J. Clin. Endocrinol. Metab. 51, 1469-1471. 
6. Lopata, A., Johnston, I. W., Hoult, I. J. \& Speirs, A. E. (1983) Fertil. Steril. 40, 317-321.

7. Allain, C. C., Povu, L. S., Chan, C. S. G., Richmond, W. \& Fu, P. C. (1974) Clin. Chem. 20, 470-475.

8. Takayama, M., Itoh, S., Nagasaki, T. \& Tanimizu, I. (1977) Clin. Chim. Acta 79, 93-98.

9. Levy, R. I. (1981) Clin. Chem. 27, 653-662.

10. Gidez, L. I., Miller, G. J., Burstein, M., Slagle, S. \& Eder, H. A. (1982) J. Lipid Res. 23, 1206-1223.

11. Lowry, O. H., Rosenbrough, N. J., Farr, A. L. \& Randall, R. J. (1951) J. Biol. Chem. 193, 265-275.

12. Abraham, G. E., Odell, W. D., Swerdloff, R. S. \& Hopper, K. (1972) J. Clin. Endocrinol. 34, 312-318.

13. Carson, R. S., Trounson, A. O. \& Findley, J. K. (1982) J. Clin. Endocrinol. Metab. 55, 798-800.

14. Armitage, P. (1973) Statistical Methods in Medical Research, Blackwell Scientific Publications, Oxford.

15. McNatty, K. P., Makris, A., DeGrazia, C., Osathanoudle, R. \& Ryan, K. J. (1979) J. Clin. Endocrinol. Metab. 49, 687-699.
16. Hillier, S. G. \& Wickings, E. J. (1985) In: The Luteal Phase, (Jeffcoate, S. L., ed.) pp. 1-23, John Wiley \& Sons, Chichester.

17. Berger, M. A., Laufer, N., Lewin, A., Navot, D., Rabinowitz, R., Fisenberg, S., Margalioth, E. \& Schenker, J. G. (1987) J. In Vitro Fertil. Embryo Transf. 4, 30-33.

18. Shalgi, R., Kraicer, P., Rimon, A., Pinto, M. \& Soferman, N. (1973) Fertil. Steril. 24, 429-434.

19. Perret, B. P., Parinaud, J., Ribbes, H., Moatti, J. P., Pontonnier, G., Chap, H. \& Douste-Blazy, L. (1985) Fertil. Steril. 43, 405-409.

20. Suchanek, E., Grizelj, V., Šimunić, V., Maćaš, E. \& Puharić, I. (1986) Proceedings of the Fifth World Congress on Human Reproduction (Aravantinos, D. \& Creatsas, G., ed.) pp. 336-339, Athens.

21. Enk, L., Crona, N. \& Hillensjö, T. (1987) Hum. Reprod. 2, $291-295$.

22. Parinaud, J., Perret, B., Ribbes, H., Chap, H., Pontonnier, G. \& Douste-Blazy, L. (1987) J. Clin. Endocrinol. Metab. $64,409-417$.

Dr. Ernest Suchanek Laboratory for Reproductive Endocrinology University Clinic of Gynecology and Obstetrics Faculty of Medicine Petrova 13

YU-4100 Zagreb

Yugoslavia 
